
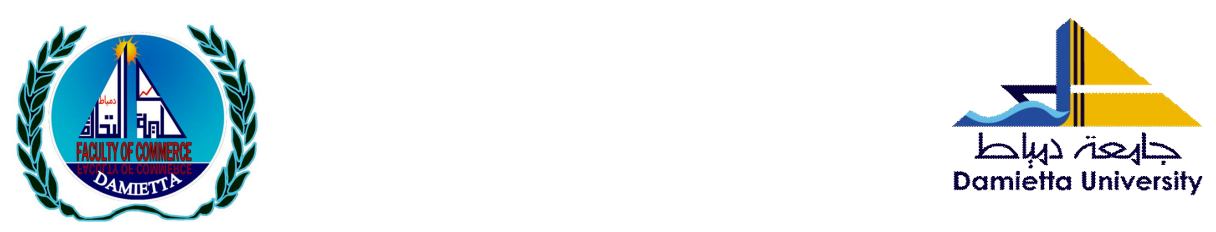

\title{
Corporate Governance and Disclosure Verifiability as Determinants of Disclosure Tone in the Egyptian Context
}

\author{
Prepared by \\ Amr Nazieh Mahmoud Ezat
}

Associate Professor, Accounting Department

Faculty of Commerce, Mansoura University

anezat@iau.edu.sa

Scientific Journal for Financial and Commercial Studies and Researches (SIFCSR)

Faculty of Commerce - Damietta University Vol.1, $\mathcal{N}(o .2$, Part 2., July 2020

APA Citation:

Ezat, A. N. M. (2020). Corporate Governance and Disclosure Verifiability as Determinants of Disclosure Tone in the Egyptian Context. Scientific Journal for Financial and Commercial Studies and Researches (SJFCSR), Vol.1 (2) Part2. pp.1-36

Website: https://cfdj.journals.ekb.eg/ 


\title{
Corporate Governance and Disclosure \\ Verifiability as Determinants of Disclosure Tone in the Egyptian Context
}

\author{
Amr Nazieh Mahmoud Ezat
}

\begin{abstract}
:
This study explores the extent to which Corporate Governance (CG) and disclosure verifiability are represented among the key determinants of disclosure tone in the context of Egyptian companies' board of directors' annual reports. The sample includes the Egyptian EGX100 companies, listed from 2013 to 2017. This study uses a panel date with fixed effect regression model to test the main hypotheses. It employs a manual content analysis which focuses on statements as a measurement unit to calculate the disclosure tone. The net positive news is captured by calculating the variance between positive news and negative news.

The results indicate that the EGX100 companies' boards of directors' annual reports disclose more positive than negative news. In addition, all board diversity variables impact on the disclosure tone of such reports. Further, CEO tenure is the only variable related to CEO power that has a significant association with disclosure tone. Similarly, when compared to backward-looking information, the disclosure of forward- looking information is more likely to have a significant relationship with disclosure tone. In addition, with the exception of company size, there is an insignificant association between all control variables and disclosure tone.

Based on the limited literature relating to developing countries' capital markets, this study contributes to the accounting literature by providing empirical evidence of CG's effect and disclosure verifiability on the disclosure tone in emerging markets.
\end{abstract}

Keywords: Corporate Governance (CG); Egypt; tone; disclosure Verifiability; Board diversity; CEO power. 


\section{Introduction}

Corporate reports represent one of the most important sources through which companies present their past events; discuss their policies and regulations; and outline their future perspectives. Narrative disclosure plays a crucial role in providing useful information to various stakeholders (Rodrigue et al., 2015). However, the wording of the narrative disclosure is arbitrary and is not subject to formal auditing (Henry, 2008). Management may use these narratives through impression management hypotheses to be self- serving and biased to disclosing their favourable performance to either protect their interests or to present themselves in better situations (Keusch et al., 2012). Company's management seek to present their performance in the best situation by using selective financial disclosure to influence the images held by others (Bolino and Turnley, 1999; Clatworthy and Jones, 2003).

Stylistic attributes can aid management to achieve this intention. One of these attributes, which is discussed widely through accounting literatures, is the tone of corporate reports. Tone is viewed as the content that the speaker used to affect the communication with the reader through which general feeling is perceived from the text either in positive or negative emotions (Henry, 2008). Therefore, tone has an impact on the investors' perceptions and reactions due to its impact on the disclosed information (Huang et al., 2014). Companies may seek to achieve certain interests by either increasing positive or negative disclosure tone in order to reflect their performance and image. This is called tone management (Huang et al., 2014).

When investigating tone management, previous studies discussed the use of biased language and tone in the companies' annual reports. This is a form of impression management hypothesis (e.g. Cho et al., 2010; Rodrigue et al., 2015). Management can use positive and negative statements to present their intended messages to stakeholders. Disclosure tone can be defined as the use of optimistic versus pessimistic language to express different points of view (Sydserff and Weetman, 1999). Therefore, the examination of the annual reports' thematic disclosure to determine the tone of disclosed statements is an important field of research due to it being related to impression management strategy which may affect disclosure quality (Brennan and Merkl-Davies, 2013). 
In addition, the association between disclosure tone and some company characteristics variables are examined in the context of the impression management hypothesis. One of these characteristics is CG variables which impact on the use of thematic manipulation (Melloni et al., 2016). According to agency theory, CG variables may mitigate the impact of impression management strategies through the board of directors' rigid control of management duties.

Further, based on stewardship theory, management act in the line with the shareholders to provide good stewardship of the company's assets since both interests have a congruence goal (Donaldson and Davis, 1991). In this situation, CG variables encourage this congruence through the disclosure of negative information in the company's annual reports in order to reflect its true position. This boost both the management's and the shareholders' confidence in finding the best solution to overcome these negative situations. Further and, more especially when achieving poor financial indicators, management may disclose negative disclosure in order to avoid accountability to shareholders and to attribute this bad situation to the external environment rather than to their actions. Accordingly, the first main objective is to examine the association between CG variables and the tone of the disclosure in the Egyptian context.

In addition, based on the attribution theory, management may attribute positive news to the internal success of their efforts and may attribute negative news to the company's external environment (Clatworthy and Jones, 2003). One way of dealing with this attribution is to examine the characteristics of disclosure. Mercer (2004) mentioned that the creditability of disclosure had to be examined for each disclosure item. Therefore, this study's second objective is to examine the association between disclosure verifiability and the tone of disclosure in the Egyptian context.

Several reasons justified this study's motivation to consider the Egyptian context. First, in addition to updating the accounting and auditing standards which attract foreign investments, the Egyptian Government has taken steps to improve the preparation and transparency of financial reporting, (Elsayed and Hoque, 2010). Second, the Egyptian environment has been exposed to some events during the last ten years that have impacted on the Egyptian economic and political systems. 
These have affected the accounting disclosure practices and increased the motivation to conduct this study (Aly, 2018). Third, there has been little research done on Egypt's CG structure. In recent years, several reforms have been made to the Egyptian CG code. Despite the multiple updates to the $\mathrm{CG}$ code, previous studies have reported some continuing weaknesses in relation to board responsibilities, disclosure and transparency (Ebrahim and Fattah, 2015). Egypt's CG structure is characterized by unique attributes that affect narrative disclosures and the tone of corporate reports.

This study contributes to the existing literature in two ways. First, most of the studies, which discussed the tone of disclosure, applied to the developed countries. Few studies examined such topic in the context of developing countries and, more specifically, Egypt (e.g. Aly et al. 2018). Therefore, this study explores the tone of disclosure for the Egyptian EGX 100 listed companies during the period from 2013 to 2017. Second, in considering the unique Egyptian CG characteristics, this study examines the association between some $\mathrm{CG}$ variables, i.e. women members and COE power, that have not received considerable attention in the previous studies of developing countries. Third, the accounting literature has examined rarely the impact of disclosure verifiability on disclosure tone. Therefore, this study adds to previous studies by investigating such an association.

The rest of the paper is organized as follows. Section 2 introduces the theoretical framework; discusses briefly the previous literature and the formulation of the hypotheses. Section 3 presents the research methodology. Section 4 discusses the empirical findings and Section 5 presents the conclusions.

\section{Theoretical framework, literature review and hypotheses formulation}

Agency theory presents the conflict between management and shareholders which result in information asymmetry problems. One way of mitigating this conflict is to widen the level of monitoring and apply a CG mechanism to control the board of directors' actions. Thus, management cannot behave opportunistically and cannot self-serve. This suggests that there would be a reduction in the level of positive disclosure tone. On the other hand, when there is a weak CG structure, management have the opportunity and the power to apply impression 
management strategy. Consequently, these actions inhibit the board of directors' ability to monitor the management and, hence, increase the level of positive disclosure tone to hide poor performance so that management achieves certain self-serving interests over the shareholders (Huang et al., 2014).

In addition, signalling theory explains that management signals their good performance by extending the level of disclosure. When explaining the reason to extend the optimistic disclosure tone, some studies embraced the incremental information strategy. Their findings show that there is a positive association between optimistic disclosure tone and good performance. This suggests that management encourages the increasing of optimistic disclosure tone as a reason to satisfy investors (Feldman et al., 2010; Davis et al., 2012; Patelli and Pedrini, 2014; Buchholz et al., 2018).

On the other hand, based on the stewardship theory, company's management may share the same goal as the shareholders. This explains the management's willingness to disclose negative rather than positive information in order to reflect the company's true image. In order to find the best solution to solve these negative events, the management needs to share the negative situation with their shareholders instead of deceiving them. Further, management may disclose negative information to blame the external environment for the company's poor performance and to deflect their irresponsibility for these situations (Ressas and Hussainey, 2014).

Previous studies paid much attention to textual information when exploring whether or not language represents one of the sources that provide investors with meaningful information about a company's performance, risks, restrictions and future events (e.g. Henry, 2008; Smith and Taffler, 2000; Li, 2011; Dyer et al., 2016).

Existing empirical literature indicates many points that can be considered. First, the majority of previous studies were conducted in the developed countries, (e.g. Clatworthy and Jones 2003; Arena et al., 2015; Ataullah et al., 2018)

Second, previous studies used different units of analysis to measure disclosure tone. Some studies depended on the chairman's message sections, (e.g. Clatworthy and Jones 2003; Ataullah et al., 2018), while others used either corporate social responsibility reports, (e.g. Cho et el., 
2010; Arena et. al., 2015) or annual reports, (e.g. Iatridis, 2016; Aly, 2018), MD\&A, (e.g. Feldman et al., 2010; Davis et. al., 2012; Henry et. al., 2016; Dutta et. al., 2019).

Third, two main methods are employed when measuring tone. On one hand, some studies used computer-aided content analysis, (e.g. Cho et. al., 2010; Davis et. al., 2012; Arena et. al., 2015; Ataullah et al., 2018). While, on the other hand, some studies used manual content analysis (e.g. Schleicher and Walker, 2010; Melloni et. al., 2016; Aly et. al., 2018).

Fourth, previous studies used two proxies of disclosure tone as text unit. These proxies were, firstly, the number of words (e.g. Clatworthy and Jones, 2003; Cho et. al., 2010; Davis et. al., 2012; Arena et. al., 2015; Ataullah et al., 2018) and, secondly, the number of statements, (e.g. Schleicher and Walker, 2010; Melloni et. al., 2016; Aly et. al., 2018).

Fifth, many previous studies examined the antecedents of disclosure tone. Most of these studies concentrated mainly on company characteristics, e.g. firm environmental performance (Cho et. al., 2010), company size (Davis et. al., 2012), industry type (Dutta et. al., 2019), company age (Aly et. al., 2010), profitability (Keusch et. al., 2012), firm performance (Davis et. al., 2012; Aly et. al., 2018), internal control system (Rich et. al., 2018), company failure (Smith and Taffler, 2000), earning manipulation (Iatridis, 2016) and firm growth (Davis et. al., 2012; Dutta et. al., 2019).

In addition, some studies examined the value relevance of disclosure tone. Different variables are affected by disclosure tone, e.g. leverage (Ataullah et al., 2018), frim performance (Abrahamson and Amir, 1996; Aly et. al., 2018), cumulative abnormal returns (Henry, 2008), financial reporting quality (Rich et. al., 2016) and cost of capital (Kothari et al., 2009)

However, few studies examined the relationship between CG and disclosure verifiability variables and disclosure tone. This study fills this gap.

By using a sample of 265 publicly listed Spanish firms, Osma and Saorin (2011) explored the relationship between the disclosure tone as a proxy for impression management and the CG structure. Disclosure tone 
is measured by coding key words and statements with positive and negative connotation in the Presidents' letters sections. This study provides evidence of CG's impact on the impression management in annual press releases. Strong CG limits the prevalence of impression management for the sampled companies and due to the CG structure's monitoring role reduces self-serving disclosure by the company's management.

In addition, by using a sample of 110 UK chairman statements in their annual report narrative sections, Ressas and Hussainey (2014) examined the impact of the financial crisis on financial reporting of good news and bad news. This study uses manual content analysis to identify the good and bad news statements disclosed in the chairman's section. After controlling for some firm characteristics and CG variables, the results indicate that UK financial companies disclosed more bad news during and after the crisis period. Both board size and board composition are significant only with good news disclosure.

Further, by using a sample of 288 US oil and gas firms, Arena et al. (2015) investigated the role of the board of directors' monitoring and stakeholder orientation in shaping the relationship between environmental disclosure tone and future environmental performance. By performing a computer-aided content analysis, this study calculated the tone of environmental disclosure in the 10-Kfilings. In addition, the study explored whether the optimistic language in the environmental disclosure was a discretionary strategy associated with forward-looking disclosure. The results illustrated that optimism was associated negatively with future environmental concerns only for companies with low board monitoring and the ones with high stakeholder orientation. This finding suggests that companies with a highly stakeholder-oriented board tend to have forward-looking disclosure.

By focusing on the Integrated Report (IR), Melloni et al. (2016) performed two levels of analysis. The first was a manual content analysis for coding the disclosed statements in the IR's business model section. The study distinguished between positive and non-positive statements when calculating the disclosure tone. The second was a multivariate analysis to test the association between disclosure tone and CG variables, performance and disclosure verifiability. On average, the results indicated that most of the IR disclosed non-positive tone. In addition, 
companies with larger boards and forward-looking information were associated with an increased optimistic tone.

Similarly, Martikainen et al. (2016) examined whether the companies' boards of directors impacted the disclosure tone in the10-K annual reports. This study used Loughran and McDonald's (2011) dictionary to capture lists of words that calculated the following four tone measures: namely, negative; positive; uncertainty; and litigious. The cross-sectional OLS regression analysis provides an empirical evidence of the impact of directors' risk aversion/experiences, uniformity, human capital and turnover in respect of all types of disclosure tone.

In the UK, Yan (2017) studied the impact of CG on the disclosure of Intellectual Capital (IC) in the CEOs' statement sections of the annual reports. The study depended on the content analysis of a sample of 78 FTSE 100 companies to capture three dependent variables. One of these dependant variables is the tone of IC disclosure; this is measured by the number of sentences related to IC that are disclosed in the CEOs' statements. The multiple regression results indicate that board composition is the only CG variables that impacts on the tone of IC disclosure.

Recently, DeBoskey et al, (2019) constructed a model to test the relationship between earnings announcement and CEO power with and without the moderating effect of board monitoring. Based on the number of words obtained from Loughran and McDonald's (2011) dictionary, this study calculated the tone of earnings announcement. The results demonstrated that both CEO tenure and role duality were associated positively with tone. Further, CG variables moderate only the effect of $\mathrm{CEO}$ tenure on disclosure tone. However, there is no evidence to support the CG moderation effect of role duality on disclosure tone.

Accordingly, to a large extent, the impact of CG variables on the disclosure tone has not been examined in the developed countries. Moreover, in the context of developing countries, there has not been considerable interest in such an association. Therefore, this study seeks to fill the gap by examining the impact of different $C G$ and disclosure verifiability variables on the tone of disclosed statements in the Egyptian listed companies' board of directors' annual reports during the period from 2013 to 2017. 


\subsection{The association between CG variables and tone disclosure}

The link between CG structure and disclosure tone can be explained by two different theories and hypotheses. According to agency theory, there is an information asymmetry between management and shareholders in which management has more information than shareholders. Therefore, as a result of the impression management hypothesis, management has opportunities to manipulate the disclosed thematic statements in the company's reports to maximise their own interests. Management may disclose more optimistic information to achieve specific interests. One way of alleviating this problem is to use $\mathrm{CG}$ structure to monitor and restrict the management's role. Accordingly, good CG is expected to reduce the level of net positive disclosure tone.

On the other hand, when management has the power over the other members on the board, it becomes self-serving and performs the impression management strategy which enables it to behave opportunistically in order to achieve specific interests over the shareholders. In this situation, CG represents a weak structure and does not perform the required monitoring and controlling role on the management. Therefore, it is expected that in a weak CG construct the level of net positive disclosure tone increases.

This study classifies the CG variables into two main groups. The first is board diversity variables and the second is CEO power variables.

\subsubsection{Board diversity variables}

Three variables constitute the board diversity. Firstly, gender diversity is the number of women members on the board. Secondly, nationality diversity is the number of foreign members on the board. Thirdly, duty diversity is the number of non-executives members on the board.

\subsubsection{Gender diversity}

Gender diversity refers to the representation of women on the board. Two different points of views discussed the value of diversity. The first advocated the value of diversity and suggested that heterogeneity would offer better perspectives for resolving problem, supporting their teams and enabling higher quality decisions and better disclosure (e.g. Zang et al. 2013; Liao et al., 2015). However, the second doubted about this value and argued that more diversity on the board of directors would 
enhance the agency problems through increasing the conflict on the board. This would reduce the level of cooperation between board members and create misunderstandings and, hence, would incur more potential costs (e.g.Lau and Murnighan,1998;Herring, 2009).

Regarding the proponents of the value of diversity, many previous studies embraced the idea that diversity on the board had a positive impact on board activity, firm performance and reporting quality. They explained this trend through agency theory which illustrated that greater diversity on the board would mitigate the conflict between management and shareholders. This would be achieved through increasing the monitoring and control of management and by reinforcing the CG structure through female members' unique characteristics such as diligence, commitment in attending board meetings, less assertiveness and being more risk-averse, being less optimistic and less overconfident (e.g. Fellner and Maciejovsky 2007; Adams and Ferreira, 2009; Ho et al., 2015; Davis et. al. 2015; Ginesti et al., 2019). Consequently, based on this view and when compared to male managers, female managers are expected to disclose a less positive tone.

In the Egyptian context, some boards have female members. However, according to (Cigna et al., 2017), the weakness of this number needs to be examined more closely. Therefore, since this variable is examined rarely in the context of developing countries and, more especially Egypt, this study examines women members' impact on the disclosure tone. Accordingly, the first hypothesis is:

\section{$H_{1}$ : There is a significant relationship between women members on the board and disclosure tone.}

\subsubsection{Nationality diversity}

Due to such members' different cultures, the presence of foreign members on the board can provide diversity in experience, knowledge, capabilities and skills. Accordingly, due to their unique characteristics that will lead the companies to differentiate themselves by disclosing more optimistic information, foreign members can enhance the board's performance. Therefore, based on signalling theory, these companies may tend to signal their good performance to their shareholders by increasing their positive disclosure tone. 
On the other hand, based on the agency theory, increasing the number of foreign members increases the board's monitoring and controlling role of the management's actions and, hence, reduces the positive disclosure tone.

Few studies investigate the impact of foreign members' presence on disclosure. While Shehata, (2017) and Ezat (2019) report that there is a significant relationship between foreign members and disclosure, Ebrahim and Fattah, (2015) find this relationship to be insignificant.

Many boards of Egyptian listed companies include foreign members. Consistent with the above argument, it can be suggested that foreign members on Egyptian companies' boards impact on disclosure tone. Consequently, this study's second hypothesis is:

\section{$\mathrm{H}_{2}$ : There is a significant relationship between foreign members on the board and disclosure tone.}

\subsubsection{Duty diversity}

Non-executive directors are the directors on a company's board other than managing and functional directors. This variable determines the diversity in duty between the proportion of executive directors (inside the company) and the non-executive directors (outside the company).

Agency theory explains the benefit of increasing the number of non-executive directors to protect the shareholders' interests due to their monitoring role of the management's actions. This suggests that increasing the number of non-executive directors reduces the positive disclosure tone. While some previous studies supported this argument (e.g. Osma and Saorin, 2011; Yan, 2017), others did not (e.g. Ressas and Hussainey, 2014; Arena et al., 2015).

On the other hand, the opponents of non-executive directors being a majority on the board argue that they do not have enough information about the companies' activities and may lack real independence. Such circumstances enable management to perform opportunistic actions to achieve their main benefits (Baysinger and Butler, 1985; Goodstein et al., 1994). Accordingly, due to the lack of their independence, increasing the number of non-executive members increases the level of positive disclosure tone.

The Egyptian CG code specifies only that there should be no more than three executive members on the board. This means that most are 
non-executives. Based on the above arguments, this study's third hypothesis is:

\section{$\mathrm{H}_{3}$ : There is a significant relationship between non-executive directors on the board and disclosure tone.}

\subsubsection{CEO power variables}

Power refers to 'the capacity of individuals to exert their will' (Finkelstein 1992). Power enables CEOs to have greater access and more control on the various resources through which there is a significant effect on the company's performance. CEO power can influence the disclosure tone through the CEO's authority to appoint directors and officers who share the same style and preferences. This guarantees their loyalty and allows the CEO to exercise more power on reporting judgement and disclosure decisions (DeBoskey et al., 2019).

CEO power relates to excessive risk taking (Lewellyn and MullerKahle, 2012). This suggests that increasing the optimistic disclosure tone is associated with the more powerful CEOs' who have higher tolerance towards the risks associated with litigation and regulatory enforcement (Deboskey et al., 2019).

Finkelstein (2009) (as cited in Lewellyn andMuller-Kahle, 2012, P.4) argued that there are no compelling theoretical explanations to use only one measure for CEO power. Therefore, this study includes three main variables to measure $\mathrm{CEO}$ power. First, there is expert power which is the number of years that the CEO sits on the board (CEO tenure). Second, there is structural power which is the CEO-chairman duality (role duality). Third, there is ownership power which is the percentage of shares held by the CEO (CEO ownership).

\subsubsection{CEO tenure}

Expert power refers to the comprehensive knowledge that may differentiate the CEO from any other board members and may enable him to exert control over them as a result of his wide understanding of the company's operations and its environment (Lewellyn and MullerKahle, 2012).

Increased power over time enables the CEO to use the long relationships, developed with different members either inside or outside the board, to control the flow of information, the allocation of resources. Therefore, longer tenures allow managers to increase their knowledge 
which, in turn, increases their power. This leads CEOs to take more risks by adopting risky actions; to be more opportunistic due to the impression management strategy (Shen, 2003); and to have more monitoring on the board members (Shivdasani and Yermack, 1999). These result in disclosing a more positive tone to protect their interests.

Previous studies' findings show that CEO tenure is associated positively and significantly with financial reporting quality (Hazarika et al., 2012). In addition, Deboskey et al., (2019) indicates that tenure is associated positively with tone.

Based on the above arguments, this study's fourth hypothesis is:

$H_{4}$ : There is a significant relationship between CEO tenure and disclosure tone.

\subsubsection{Role duality}

Role duality occurs between a CEO and a chairman when one of them holds both positions simultaneously (i.e. when the CEO is, also, chairman of the board). In this situation, CEO holds the two highest positions; this leads to the concentration of both power and authority in one person (Donaldson and Davis, 1991; Van Essen et al., 2015).

In such circumstances, based on agency theory, the board's monitoring role of the CEO is weakened. This suggests that the CEO can perform any action compatible with their interests and express their impressions that result in increasing the positive disclosure tone.

Some empirical studies have revealed a significant positive relationship between role duality and disclosure (Deboskey et al., 2019), while others have found this relationship to be insignificant (Osma and Saorin, 2011). In addition, Ginesti et al. (2017) findings show that role duality has a negative impact on the MD\&A's disclosure quality

In Egypt, one person may hold both the power and authority roles responsible for management and is called executive director (Elsayed et al., 2010). Consequently, this study's fifth hypothesis is:

$H_{5}$ : There is a significant relationship between role duality and disclosure tone.

\subsubsection{CEO ownership}

CEO ownership refers to the proportion of the company's shares held by the CEO. Similar to the previous variables of CEO power, CEOs 
with shareholdings represent both management and shareholders. This allows them to exercise power over the other board members and, hence, by disclosing an optimistic tone, they engage more in self-service disclosure practices (Wu, and $\mathrm{Xu}, 2011$; Arslan-Ayaydin et al., 2016).

In addition, CEOs may be risk averse when holding a stake in the company's ownership structure and be more willing to maximize the company's value to maximize their stake and, hence, to minimize the bad effect that their tone may have on their portfolio value. This suggests disclosing a more positive and optimistic tone in their reports (ArslanAyaydin et al., 2016).

Previous studies provide empirical evidence to support this argument. DeBoskey et al., (2019) indicate a positive association between CEO ownership and tone. In addition, Arslan-Ayaydin et al., (2016) reach the same conclusions. Further, Kim and Lu, (2011) indicate that CEO ownership has a positive impact on the company's value.

Consequently, this study's sixth hypothesis is:

\section{$H_{6}$ : There is a significant relationship between CEO ownership and disclosure tone.}

\subsection{The association between disclosure verifiability and disclosure tone}

In order to determine whether the disclosure tone is subject to impression management strategy and, hence, thematic manipulation or is subject to incremental information strategy due to good performance, this study tests not only CG variables but, also, some disclosure variables, i.e. disclosure verifiability.

According to impression management strategy, management may increase the level of positive disclosure that protects their interests and achieves their objectives. In addition, signalling theory postulates that management may signal their good performance to shareholder through enlarging the disclosure thematic. In this situation, there is goal congruence between both the management's and the shareholders' interests. Therefore, the incremental information hypothesis is that management discloses more optimistic information to signal the company's good performance.

Disclosure verifiability is defined as the creditability of disclosure conveyed to investors (Mercer, 2004). Previous studies illustrate the 
importance of variations in each company's individual disclosure creditability to investors (Williams, 1996).

This study investigates two kinds of disclosure: namely, disclosure time; and disclosure type. The higher value of both disclosure type (quantitative information) and disclosure time (backward-looking information) indicate the higher disclosure verifiability and, hence, the less positive disclosure tone (Melloni et al., 2016).

\subsubsection{Disclosure type}

With regard to the disclosure type (quantitative disclosure vs. nonquantitative disclosure), Melloni et al., (2016) asserts that quantitative disclosure is more verified than non- quantitative ones. Further, Dobler et al. (2011) mentions that management may withhold quantitative information due to their discretion to disclose information in order to avoid any unfavourable consequences of disclosures. This suggests that unverified disclosure, such as non-quantitative information, is subject to greater discretion than verified disclosure such as quantitative information.

\subsubsection{Disclosure time}

Regarding disclosure time (forward- looking disclosure vs. backward-looking disclosure), (Schleicher and Walker, 2010) focused on the tone of forward- looking disclosure due to its usefulness, predictive value, and value relevance in terms of backward-looking disclosure. They suggested that impression management strategy would increase the management's willingness to disclose more forward-looking disclosure.

In addition, by using a sample of UK narrative statements from 2005 to 2011, Hassanein and Hussainey (2015) investigated if forwardlooking financial disclosure changed in response to changes in firm performance for. They found that, when compared to companies that performed well, poorly performing firms were more willing to change their forward-looking disclosures.

Consequently, based on agency theory, management may reduce information asymmetry problems by disclosing more verifiable information (quantitative and backward-looking information) and reflect the incremental information strategy through increasing the positive disclosure tone. This suggests that disclosing verifiable information is associated with positive disclosure tone. 
On the other hand, signalling theory explains the management's willingness to withhold verifiable information in order to avoid the disclosure of the poor signals and less verifiable information (i.e. qualitative and forward-looking information). This reflects its impression strategy through the disclosure tone and suggests that disclosing less verifiable information is associated with positive disclosure tone.

Based on the above arguments, this study's seventh and eighth hypotheses are:

$H_{7}$ : There is a significant relationship between disclosure type and disclosure tone.

$H_{8}$ : There is a significant relationship between disclosure time and disclosure tone.

\section{Methodology}

\subsection{Sample}

The board of directors' annual reports is this study's unit of analysis. Therefore, the initial sample includes the board reports of the EGX most actively traded 100 companies from 2013 to 2017 . I obtained the annual reports from the Egypt for Information Dissemination (EGID) database and the companies' websites. In addition, I obtained the data, used to calculate the independent and the other control variables, from their financial statements. Due to the unavailability of data for some companies, I excluded the companies with missing observations. In addition, some of the sampled companies are listed after the study period and resulted in inequality in the observations related to the study period. The final sample's results consist of 445 observations. Table 1 presents the initial and final samples.

Table 1: The initial and final sample

\begin{tabular}{|l|c|}
\hline \multicolumn{1}{|c|}{ Description } & $\begin{array}{c}\text { Number of } \\
\text { observations }\end{array}$ \\
\hline Initial sample (95 Companies *5 years) & 475 \\
\hline Plus: some listed companies after the study period & \\
(1 company * 4 years) & 4 \\
(3 companies * 3 years) & 9 \\
1 company * 2 years $)$ & 2 \\
\hline Less: unavailable board reports & $(45)$ \\
\hline Final Size & 445 \\
\hline
\end{tabular}




\subsection{Research design}

\subsubsection{Measurement of disclosure tone}

As the companies' annual reports were written in Arabic, this study used manual content analysis to capture disclosure tone. Following (Schleicher, 2012; Rodrigue et al., 2015; Melloni et al., 2016; Aly et al., 2018), this study considers the statements in the board reports as units of measurement. This approach is called "meaning -orientated" and differs from the "form-orientated" approach used by other studies, (e.g. Schleicher, 2012). By focusing on manual content analysis and statements, - despite their discomfort - this study guaranteed the required more sensitive and subjective approach when analyzing the narrative disclosure (Clatworth and Jones, 2003). In addition, engaged on the manual content analysis by counting the number of statements concentrates on the meaning of the statements rather than coding only the words which aids to interpreting the whole statements and counting them as either positive or negative.

This study counted the number of good news statements (optimistic or positive tone) and bad news statements (pessimistic or negative tone) to calculate disclosure tone. (Aly et al. 2018). The statements are classified to be positive or negative if they indicated good (beneficial activity) or bad news (detrimental attitude) for either the company itself or the environment in which it operated (Gray et al., 1995; Clatworth and Jones, 2003; Rodrigue et al., 2015; Melloni et al., 2016). In addition, to test the validity of tone measurement, the study followed Aly et al. (2018) by distributing a sample of the annual board reports to a professional accountant to count the number of good and bad news statements.

\subsubsection{Measurement of independent and control variables}

This study's three main groups of independent variables were board diversity variables, CEO power variables and disclosure verifiability variables. Table 2 summarizes these variables and their proxies.

In addition, this study included company's size (size), risk (Lev), profitability (prof) and industry type (Type) as four control variables, the literature described commonly that examined as having a significant relationship with tone. Table 2 illustrates, also, the proxies of the control variables. 
Amr Nazieh Mahmoud Ezat

Table 2: The variable definitions and their proxies

\begin{tabular}{|c|c|c|}
\hline Variable & Acronym & Proxy \\
\hline \multicolumn{3}{|l|}{ Dependent Variable: } \\
\hline Disclosure Tone & Tone & Net news (positive news-negative news) \\
\hline \multicolumn{3}{|l|}{ Independent Variables: } \\
\hline \multicolumn{3}{|l|}{$\begin{array}{l}\text { (A) Board diversity } \\
\text { variables }\end{array}$} \\
\hline Women members & Wom & $\begin{array}{l}\text { The ratio of woman numbers to the total } \\
\text { members on the board }\end{array}$ \\
\hline Foreign members & For & $\begin{array}{l}\text { Dummy variable equal to } 1 \text { if there is a } \\
\text { foreign member on the board, } 0 \\
\text { otherwise }\end{array}$ \\
\hline Non-executive members & $N E x$ & $\begin{array}{l}\text { The ratio of non-executive members to } \\
\text { the total members on the board. }\end{array}$ \\
\hline \multicolumn{3}{|l|}{ (B) CEO power Variables } \\
\hline CEO Tenure & Ten & $\begin{array}{l}\text { The number of years an individual has } \\
\text { been the CEO }\end{array}$ \\
\hline Role duality & $R D$ & $\begin{array}{l}\text { Dummy variable equal to } 1 \text { if the } \\
\text { chairman is the same person as the CEO, } \\
0 \text { otherwise }\end{array}$ \\
\hline CEO ownership & Own & $\begin{array}{l}\text { The number of shares held by COE } \\
\text { deflated by the total outstanding shares }\end{array}$ \\
\hline \multicolumn{3}{|l|}{$\begin{array}{l}\text { (C) Disclosure verifiability } \\
\text { Variables }\end{array}$} \\
\hline Disclosure Type & Dis Type & $\begin{array}{l}\text { The number of quantitative statements } \\
\text { deflated by the total number of the } \\
\text { statements of the board report }\end{array}$ \\
\hline Disclosure Time & Dis Time & $\begin{array}{l}\text { The number of non- forward-looking } \\
\text { statements deflated by the total number } \\
\text { of the statements of the board report }\end{array}$ \\
\hline \multicolumn{3}{|l|}{ Control variables: } \\
\hline Size & size & Natural logarithm of total assets \\
\hline Risk & Lev & Total liabilities deflated by total equity \\
\hline Profitability & prof & Net profit deflated by total equity \\
\hline Industry Type & Type & $\begin{array}{l}\text { Dummy variable equal to } 1 \text { if the } \\
\text { company belongs to financial and banks } \\
\text { sector, } 0 \text { otherwise }\end{array}$ \\
\hline
\end{tabular}




\subsubsection{Research model}

In order to test the hypotheses, this study depended on panel date with fixed effect and constructed the following Ordinary Least Squares (OLS) model:

$$
\begin{aligned}
\text { Tone }= & \beta_{0}+\beta_{1} \text { Wom }+\beta_{2} \text { For }+\beta_{3} \text { NEx }+\beta_{4} \text { Ten }+\beta_{5} R D+\beta_{6} \text { Own }+\beta_{7} \\
& \text { Dis Type }+\beta_{8} \text { Dis Time }+\beta_{9} \text { Size }+\beta_{10} \text { Lev }+\beta_{11} \text { Prof }+\beta_{12} \text { Type } \\
& +\boldsymbol{\varepsilon}
\end{aligned}
$$

\section{Results and discussion}

\subsection{Descriptive and univariant analysis}

Table 3 presents the content analysis of the EGX100 companies' board reports. On average, these disclose narrative positive, negative, net statements at $15.36,4.87$ and 10.51 respectively. This suggests that most of the sampled companies disclosed positive information. The results demonstrate positive variances between good and bad news over the five years and indicate that they disclosed more positive rather than negative news from 2013 to 2017. This result is consistent with Keusch et al.'s (2012) and Aly et al.'s (2018) findings. In addition, most companies disclosed non-forward-looking information which ranged between 0 and 220 statements with a mean of 25.47 while forward-looking information ranged between 0 and 33 statements with a mean of 1.95. Both quantitative and qualitative disclosures are approximately close to each other with a mean of 15.40 and 12.11 respectively.

Table 3: Descriptive of content analysis

\begin{tabular}{|l|c|c|c|c|c|}
\hline Variable & Obs. & Mean & Min. & Max. & Std. Dev. \\
\hline Good News & 445 & 15.36 & 0 & 101 & 16.52 \\
\hline Bad News & 445 & 4.87 & 0 & 46 & 6.56 \\
\hline Net news & 445 & 10.51 & -26 & 78 & 14.33 \\
\hline Backward-looking information & 445 & 25.47 & 0 & 220 & 28.58 \\
\hline Forward- looking information & 445 & 1.95 & 0 & 33 & 3.84 \\
\hline Quantitative information & 445 & 15.40 & 0 & 111 & 15.57 \\
\hline Qualitative information & 445 & 12.11 & 0 & 151 & 18.21 \\
\hline
\end{tabular}

Table 4 illustrates the descriptive findings of the other independent variables. Most Egyptian board members are non- executive with a mean of .75 . However, the percentage of women members on the board is very low at $8 \%$. With regard to the CEOs, they sit, on average, six years with 
Amr Nazieh Mahmoud Ezat

$3 \%$ being owners. Further, about $61 \%$ of the sampled companies had role duality and $38 \%$ had foreign representatives. Table 4 presents, also, the descriptive results for the control variables.

Table 4: Descriptive analysis of variables

\begin{tabular}{|c|c|c|c|c|c|}
\hline Variable & Obs. & Mean & Min. & Max. & $\begin{array}{l}\text { Std. } \\
\text { Dev. }\end{array}$ \\
\hline Wom & 445 & 0.08 & 0 & 0.5 & 0.11 \\
\hline NEx & 445 & 0.74 & 0.14 & 1 & 14.33 \\
\hline Ten & 445 & 6.16 & 0 & 20 & 5.13 \\
\hline Own & 445 & 0.03 & 0 & 0.56 & 0.07 \\
\hline Size & 445 & 9.31 & 7.49 & 11.47 & 0.84 \\
\hline Lev & 445 & 3.03 & 0.001 & 181.26 & 9.87 \\
\hline Prof & 445 & -.03 & -41.37 & 4.33 & 2.03 \\
\hline Dummy Variable & \multicolumn{3}{|l|}{ Frequency } & \multicolumn{2}{|l|}{$\%$} \\
\hline \multicolumn{6}{|l|}{ For } \\
\hline Existence & \multicolumn{3}{|l|}{168} & \multicolumn{2}{|l|}{37.75} \\
\hline Not Existence & \multicolumn{2}{|l|}{227} & \multicolumn{3}{|c|}{62.25} \\
\hline \multicolumn{6}{|l|}{$\mathrm{RD}$} \\
\hline Existence & \multicolumn{3}{|l|}{270} & \multicolumn{2}{|l|}{60.67} \\
\hline Not Existence & \multicolumn{2}{|l|}{175} & \multicolumn{3}{|c|}{39.33} \\
\hline \multicolumn{6}{|l|}{ Type } \\
\hline Financial & \multicolumn{3}{|l|}{81} & \multicolumn{2}{|l|}{18.20} \\
\hline Non-Financial & \multicolumn{3}{|l|}{364} & \multicolumn{2}{|l|}{81.80} \\
\hline
\end{tabular}

Table 5 reports the correlation matrix for the tested variables. Tone is correlated significantly with women members, foreign members and disclosure time. It correlates positively with the representation of both women and foreign members on the board. In addition, tone correlates positively with company's size, profitability, and industry type. However, it correlates negatively with disclosure time. No multicollinearity problem is detected since none of the correlation coefficients among the independent variables exceeded 0.80 (Gajarati, 2003, p.359). 


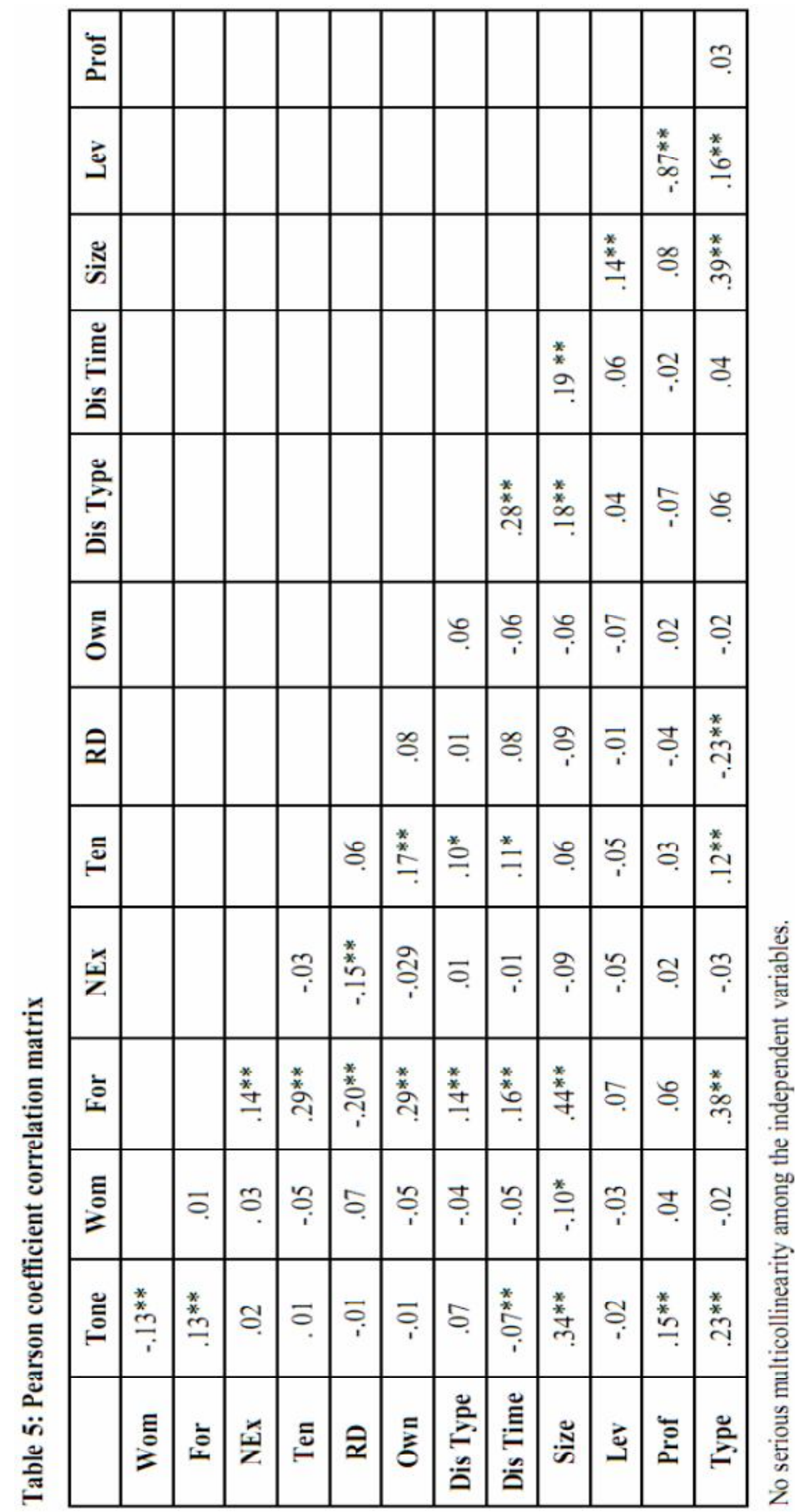




\section{Amr Nazieh Mahmoud Ezat}

\section{Multivariate analysis}

For the multivariate analysis, this study uses panel date with fixed effect by running an OLS model to test the impact of board diversity, CEO power and disclosure verifiability variables on disclosure tone. Table 5 summarises this model's results. The model is significant at $p<$ .0000 ; this indicates that the model explains the variation in the disclosure tone. The adjusted $\mathrm{R}^{2}$ is $17.32 \%$; this is comparable with Keusch et al.'s (2012), Aly et al.'s (2018) and Bakarich et al.'s (2019) findings.

Table 6: Regression results

\begin{tabular}{|c|c|}
\hline & OLS Model \\
\hline Constant & $37.16^{* * * *}$ \\
\hline Wom & $-19.83 * * *$ \\
\hline For & $-3.09 *$ \\
\hline N Ex & $3.17 * *$ \\
\hline Ten & $0.29 *$ \\
\hline $\mathrm{RD}$ & 0.92 \\
\hline Own & -.63 \\
\hline Dis Type & -3.96 \\
\hline Dis Time & $-9.89 * *$ \\
\hline Size & $5.70 * * *$ \\
\hline Lev & 0.15 \\
\hline Prof & 1.24 \\
\hline Type & 0.20 \\
\hline \multicolumn{2}{|l|}{ Other statistics } \\
\hline F-Ratio (sig.) & $9.56 * * *$ \\
\hline Adj. $R^{2}$ & .1732 \\
\hline Max. VIF & 1.60 \\
\hline
\end{tabular}

The findings reveal that all diversity variables influence disclosure tone. Duty diversity has both a significant and positive impact on disclosure tone while nationality and gender diversity have a negative impact. For hypothesis $\boldsymbol{H}_{1}$, the results indicate that the women members on the board have an impact on tone at 1 per cent. This suggests that increasing the number of women members on the board reduces the 
positive disclosure tone. This result is consistent with agency theory which supports the gender diversity on the board because women members increase the board's monitoring and controlling role of ypothesis $\boldsymbol{H}_{\boldsymbol{l}}$ is accepted.

With regard to hypothesis $\boldsymbol{H}_{2}$, which predicts a significant relationship between the existence of foreign members on the board and tone, the results show that the variables are negatively associated at 10 per cent; namely, the more foreign members on the Egyptian board, the lesser the disclosure tone. Foreign members on the board restrict the impression management strategy due to their role in controlling management and, hence, they reduce the level of disclosure tone. This is compatible with Shehata's (2017) finding. Therefore, hypothesis $\boldsymbol{H}_{2}$ is accepted.

In addition, the empirical findings show that non-executive members on the board have an impact on disclosure tone at 5 per cent. Increasing the number of non-executive members on the board will not provide them with a controlling role. Instead they may suffer from real independence. Some reasons explain this result. First, non-executive members can hold a percentage of the company's shareholding which may lead non-executive to be more self- interested and less independent. In addition, non-executive members can sit on the board for long periods of time and this enables them to make close relationships with the other board members and, hence, minimises their independence (Yan, 2017). Accordingly, the higher the number of non-executive members on the board, the more positive disclosure tone. This finding is consistent with Osma and Saorin's (2011); Eng and Mak's (2003); and Yan's (2017) findings, therefore, hypothesis $\boldsymbol{H}_{3}$ is accepted.

Regarding the CEO power, with the exception of CEO tenure, all the related variables have an insignificant association with disclosure tone. The findings demonstrate that increasing the years in which CEO sits on the board increases the disclosure tone at 10 per cent. Longer tenures enable CEOs to increase their communication with others, increase their control and, hence, their power to control the other board members. According to impression management strategy, this leads to an increased positive disclosure tone. Among others, DeBoskey et al.'s (2019) findings confirm this result. Consequently, hypothesis $\boldsymbol{H}_{4}$ is accepted. 
Disclosure verifiability has mixed results. While disclosure time has a significant impact on disclosure tone, this is not case with disclosure type. The findings indicate that disclosing forward-looking information has a significant impact on disclosure tone at 5 per cent. This suggests that disclosure tone is subject to impression management strategy. EGX100 companies focus on the tone of forward-looking information in their annual board reports and their managements are willing to attract their investors by disclosing more forward-looking information and, hence, they increase the positive disclosure tone which supports this attitude. Melloni et al., (2016) provide empirical evidence that supports these results. Therefore, hypothesis $\boldsymbol{H}_{\boldsymbol{\delta}}$ is accepted.

With regard to the control variables, only company's size has a significant impact on disclosure tone. The findings reveal that large companies are more likely to disclose more positive information. This finding is consistent with Cho et al.'s (2010) and Arena et al.'s (2015) findings.

\section{Conclusion}

This study extends previous studies on narrative disclosure by exploring the tone of disclosed information in the context of the Egyptian EGX100 companies' board of directors' annual reports from 2013 to 2017. Unlike previous studies in the developing countries, this study investigated empirically the impact of different $\mathrm{CG}$ variables i.e. board diversity and CEO power and disclosure verifiability on disclosure tone. In order to test the formulated hypotheses, this study employed panel date regression analysis.

The descriptive results indicate that the majority of the EGX 100 companies disclosed more positive than negative information. In addition, most of the disclosed information was backward- looking and quantitative. In addition, the multivariate analysis provides empirical evidence of the impact of all board diversity variables, some CEO power and disclosure verifiability variables. The findings illustrate that disclosure tone is associated positively with the number of non-executive board members and CEO tenure. While, on the other hand, there is a negative association between disclosure tone on one side and disclosure time and both women and foreign board members on the other side.

These findings are important for academic researchers because they extend the findings of the previous studies that explored the antecedents 
of disclosure tone in different contexts. This study's findings encourage the researchers to conduct further tests of the key determinants of disclosure tone in the Middle East region. In addition, this study provides some explanation in the field of impression management strategy which may aid the researchers in this area. Further, this study examined some CG variables such as CEO power and women board members in the context of developing countries, especially Egypt, which will be of value to interested researchers. For regulators, this study focused on the disclosure tone of the unaudited Egyptian EGX 100 companies' board of directors' annual reports. Regulatory bodies may consider this study helpful in monitoring the disclosure of positive and negative tone in these reports.

This study focused on EGX100 companies from 2013 to 2017. Future research can extend both the sample and time period. This study used statements as a text measured unit. Future research in the Egyptian context may measure disclosure tone by capturing the positive and negative words. In addition, future research may extend this study by examining the impact of ownership structure on tone in the Egyptian context. Further, the examination of the value relevance of disclosure tone can add more value to research in the context of developing countries. 


\section{References}

Abrahamson, E., and Amir, E. (1996) "The Information Content of The President's Letter to Shareholders", Journal of Business Finance \& Accounting, Vol. 23, No.8, pp.1157-1182.

Adams, R.B., de Haan, J., Terjesen, S. and van Ees, H. (2015) "Board diversity: Moving the field forward", Corporate Governance: An International Review, Vol. 23, No. 2, pp.77-82.

Aly, D., El-Halaby, S. and Hussainey, K. (2018) "Tone disclosure and financial performance: evidence from Egypt", Accounting Research Journal, Vol. 31, No. 1, pp.63-74.

Arena, C., Bozzolan, S. and Michelon, G. (2015) "Environmental Reporting: Transparency to Stakeholders or Stakeholder Manipulation? An Analysis of Disclosure Tone and the Role of the Board of Directors", Corporate Social Responsibility and Environmental Management, Vol. 22, No. 6, pp.346-361.

Arslan-Ayaydin, Ö., Boudt, K. and Thewissen, J. (2016) "Managers set the tone: Equity incentives and the tone of earnings press releases”, Journal of Banking \& Finance, Vol. 72, pp. S132-S147.

Ataullah, A., Vivian, A. and Xu, B. (2018) "Optimistic Disclosure Tone and Conservative Debt Policy”, Abacus, Vol. 54, No.4, pp.445-484.

Bakarich, K.M., Hossain, M. and Weintrop, J. (2019) "Different time, different tone: Company life cycle", Journal of Contemporary Accounting \& Economics, Vol. 15, No. 1, pp.69-86.

Baysinger, B.D. and Butler, H.N. (1985) "Corporate governance and the board of directors: Performance effects of changes in board composition", Journal of Law, Economics, \& Organization, Vo. 1, No. 1, pp.101-124.

Bolino, M.C. and Turnley, W.H. (1999) "Measuring impression management in organizations: A scale development based on the Jones and Pittman taxonomy", Organizational Research Methods, Vol. 2, No. 2, pp.187-206.

Brennan, N.M. and Merkl-Davies, D.M. (2013) "Accounting narratives and impression management", The Routledge companion to accounting communication, London: Routledge, pp.109-132. 
Buchholz, F., Jaeschke, R., Lopatta, K. and Maas, K. (2018) "The use of optimistic tone by narcissistic CEOs", Accounting, Auditing \& Accountability Journal, Vol. 31, No. 2, pp.531-562.

Cho, C. H., Roberts, R. W. and Patten, D. M. (2010) "The language of US corporate environmental disclosure", Accounting, Organizations and Society, Vol. 35, No. 4, pp.431-443.

Cigna, G. P., Djuric, P. and Sigheartau, A. (2017), "Corporate Governance in Transition Economies Egypt Country Report", European Bank for Reconstruction and Development.

Clatworthy, M., and Jones, M. J. (2003) "Financial reporting of good news and bad news: evidence from accounting narratives", Accounting and Business Research, Vol. 33, No. 3, pp.171-185.

Davis, A. K., Piger, J. M. and Sedor, L. M. (2012) "Beyond the Numbers: Measuring the Information Content of Earnings Press Release Language", Contemporary Accounting Research, Vol. 29, No. 3, pp.845-868.

Davis, A.K., Ge, W., Matsumoto, D. and Zhang, J.L. (2015) "The effect of manager-specific optimism on the tone of earnings conference calls", Review of Accounting Studies, Vol. 20, No. 2, pp.639-673.

DeBoskey, D.G., Luo, Y. and Zhou, L. (2019) "CEO power, board oversight, and earnings announcement tone", Review of Quantitative Finance and Accounting, Vol. 52, No. 2, pp.657-680.

Dobler, M., Lajili, K. and Zéghal, D. (2011) "Attributes of corporate risk disclosure: An international investigation in the manufacturing sector", Journal of International Accounting Research, Vol. 10, No. 2, pp.1-22.

Donaldson, L. and Davis, J.H. (1991) "Stewardship theory or agency theory: CEO governance and shareholder returns", Australian Journal of management, Vol. 16, No. 1, pp.49-64.

Dutta, S., Fuksa, M. and Macaulay, K. (2019) "Determinants of MD\&A sentiment in Canada", International Review of Economics and Finance, Vol. 60, No. C, pp.130-148.

Dyer, T., Lang, M. and Stice-Lawrence, L. (2016) "Do managers really guide through the fog? On the challenges in assessing the causes of voluntary disclosure", Journal of Accounting and Economics, Vol. 62, No. 2-3, pp.270-276. 
Ebrahim, A. and Fattah, T. A. (2015) "Corporate governance and initial compliance with IFRS in emerging markets: The case of income tax accounting in Egypt", Journal of International Accounting, Auditing and Taxation, Vol. 24, pp. 46-60

Elsayed, A. N. E., El-Masry, A. A. and Elbeltagi, I. (2010) "Corporate Governance, Firm Characteristics and Internet Financial Reporting: Evidence from Egyptian Listed Companies", Corporate ownership and Control, Vol. 7 No. 4, pp.379-427

Elsayed, M.O. and Hoque, Z. (2010) "Perceived international environmental factors and corporate voluntary disclosure practices: An empirical study", The British Accounting Review, Vol. 42, No. 1, pp.17-35.

Eng, L.L. and Mak, Y.T. (2003) "Corporate governance and voluntary disclosure", Journal of accounting and public policy, Vol. 22, No. 4, pp.325-345.

Ezat, A.N. (2019) "The impact of corporate governance structure on the readability of board of directors' report in Egyptian environment", Journal of Accounting Research, Faculty of Commerce, Tanta University, Forthcoming.

Feldman, R., Govindaraj, S., Livnat, J. and Segal, B. (2010), "Management's tone change, post earnings announcement drift and accruals", Review of Accounting Studies, Vol. 15, No. 4, pp.915953.

Fellner, G. and Maciejovsky, B. (2007) "Risk attitude and market behavior: Evidence from experimental asset markets", Journal of Economic Psychology, Vol. 28, No. 3, pp.338-350.

Finkelstein, S. (1992) "Power in top management teams: Dimensions, measurement, and validation", Academy of Management journal, Vol. 35, No. 3, pp.505-538.

Ginesti, G., Drago, C., Macchioni, R. and Sannino, G. (2018) "Female board participation and annual report readability in firms with boardroom connections", Gender in Management: An International Journal, Vol.33, No.4, pp.296-314.

Goodstein, J., Gautam, K. and Boeker, W. (1994) "The effects of board size and diversity on strategic change", Strategic management journal, Vo. 15, No. 3, pp.241-250. 
Gray, R., Kouhy, R. and Lavers, S. (1995) "Methodological themes: constructing a research database of social and environmental reporting by UK companies", Accounting, Auditing \& Accountability Journal, Vol. 8, No. 2, p.78-101.

Gujarati, D.N. (2003) Basic econometrics, 4th ed., McGraw Hill, Singapore.

Hassanein, A. and Hussainey, K. (2015) "Is forward-looking financial disclosure really informative? Evidence from UK narrative statements", International Review of Financial Analysis, Vol. 41, pp.52-61.

Hazarika, S., Karpoff, J.M. and Nahata, R. (2012) "Internal corporate governance, CEO turnover, and earnings management", Journal of Financial Economics, Vol. 104, No. 1, pp.44-69.

Henry, E. (2008) "Are investors influenced by how earnings press releases are written?", The Journal of Business Communication, Vol. 45, No. 4, pp.363-407.

Henry, E., and Leone, A. J. (2016) "Measuring Qualitative Information in Capital Markets Research: Comparison of Alternative Methodologies to Measure Disclosure Tone", The Accounting Review, Vol. 91, No. 1, pp.153-178.

Herring, C. (2009) "Does diversity pay? Race, gender, and the business case for diversity", American Sociological Review, Vol. 74, No. 2, pp.208-224.

Ho, S.S., Li, A.Y., Tam, K. and Zhang, F. (2015) "CEO gender, ethical leadership, and accounting conservatism", Journal of Business Ethics, Vol. 127, No. 2, pp.351-370.

Huang, X., Teoh, S.H. and Zhang, Y. (2013) "Tone management", The Accounting Review, Vol. 89, No. 3, pp.1083-1113.

Iatridis, G.E. (2016) "Financial reporting language in financial statements: Does pessimism restrict the potential for managerial opportunism?", International Review of Financial Analysis, Vol. 45, pp.1-17.

Keusch, T., Bollen, L. H. H. and Hassink, H. F. D. (2012) "Self-serving Bias in Annual Report Narratives: An Empirical Analysis of the Impact of Economic Crises", European Accounting Review, Vol. 21, No. 3, pp.623-648. 
Kim, E.H. and Lu, Y. (2011) "CEO ownership, external governance, and risk-taking", Journal of Financial Economics, Vol. 102, No. 2, pp.272-292.

Kothari, S. P., Li, X. and Short, J. E. (2009) "The Effect of Disclosures by Management, Analysts, and Business Press on Cost of Capital, Return Volatility, and Analyst Forecasts: A Study Using Content Analysis", The Accounting Review, Vol. 84, No. 5, pp.1639-1670.

Lau, D.C. and Murnighan, J.K. (1998), "Demographic diversity and faultines: The compositional dynamics of organizational groups", Academy of Management Review, Vol. 23, No. 2, pp.325340.

Lewellyn, K.B. and Muller-Kahle, M.I. (2012) "CEO power and risk taking: Evidence from the subprime lending industry", Corporate Governance: An International Review, Vol. 20, No. 3, pp.289-307.

Li, F. (2010) "Survey of the Literature". Journal of accounting literature, Vol. 29, pp.143-165.

Liao, L., Luo, L. and Tang, Q. (2015) "Gender diversity, board independence, environmental committee and greenhouse gas disclosure", The British Accounting Review, Vol. 47, No. 4, pp.409424.

Martikainen, M, Miihkinen, A. and Watson, L. (2016) "Board characteristics and disclosure tone", Paper presented at Florida Accounting Symposium, Tallahassee, United States, 16/09/2016 17/09/2016.

Melloni, G., Stacchezzini, R. and Lai, A. (2016) "The tone of business model disclosure: an impression management analysis of the integrated reports", Journal of Management \& Governance, vol. 20, No. 2, pp.295-320.

Mercer, M. (2004) "How do investors assess the credibility of management disclosures?", Accounting Horizons, Vol. 18, No. 3, pp.185-196.

Osma, B.G. and Guillamón-Saorín, E. (2011) “Corporate governance and impression management in annual results press releases", Accounting, Organizations and Society, Vol. 36, No. 4-5, pp.187-208. 
Patelli, L. and Pedrini, M. (2014) “Is the optimism in CEO's letters to shareholders sincere? Impression management versus communicative action during the economic crisis", Journal of Business Ethics, Vol. 124, No. 1, pp.19-34.

Ressas, M.S. and Hussainey, K. (2014) "Does financial crisis affect financial reporting of good news and bad news?", International Journal of Accounting, Auditing and Performance Evaluation, Vol. 10, No. 4, pp.410-429.

Rich, K.T., Roberts, B. and Zhang, J.X. (2016) "Linguistic Tone of Municipal Management Discussion and Analysis Disclosures and Future Financial Reporting Delays", Journal of Emerging Technologies in Accounting, Vol. 13, No. 2, pp.93-107.

Rich, K.T., Roberts, B. and Zhang, J.X. (2018) "Linguistic Tone of Municipal Management Discussion and Analysis Disclosures and Future Internal Control Quality", Journal of Governmental and Nonprofit Accounting, Forthcoming.

Rodrigue, M., Cho, C. H. and Laine, M. (2015) "Volume and Tone of Environmental Disclosure: A Comparative Analysis of a Corporation and its Stakeholders", Social and Environmental Accountability Journal, Vol. 35, No. 1, pp.1-16.

Schleicher, T. (2012) "When is good news really good news?", Accounting and Business Research, Vol. 42, No. 5, pp.547573.

Schleicher, T., and Walker, M. (2010) "Bias in the tone of forwardlooking narratives", Accounting and Business Research, Vol. 40, No. 4, pp.371-390.

Shehata, N.F. (2017) "The status and determinants of corporate governance disclosure: The case of the Gulf countries, the Journal of Developing Areas, Vol. 51, No. 4, pp.157-165.

Shen, W. (2003) "The dynamics of the CEO-board relationship: An evolutionary perspective", Academy of Management Review, Vol. 28, No. 3, pp.466-476.

Shivdasani, A. and Yermack, D. (1999) "CEO involvement in the selection of new board members: An empirical analysis", The journal of finance, Vol. 54, No. 5, pp.1829-1853. 
Smith, M., and Taffler, R. J. (2000) "The chairman's statement - A content analysis of discretionary narrative disclosures", Accounting, Auditing \& Accountability Journal, Vol. 13, No. 5, pp. 624-646.

Sydserff, R. and Weetman, P. (1999) "A texture index for evaluating accounting narratives: An alternative to readability formulas", Accounting, Auditing \& Accountability Journal, Vol. 12, No. 4, pp.459-488.

Van Essen, M., Otten, J. and Carberry, E.J. (2015) "Assessing managerial power theory: A meta-analytic approach to understanding the determinants of CEO compensation", Journal of Management, Vol. 41, No. 1, pp.164-202.

Williams, P.A. (1996) "The relation between prior earnings forecast by management and analyst response to a current management forecast", The Accounting Review, Vol. 71, No. 1, pp.103-115.

Wu, S., Quan, X. and Xu, L. (2011) "CEO power, disclosure quality and the variability of firm performance: Evidence from China", Nankai Business Review International, Vol. 2, No. 1, pp.79-97.

Yan, X. (2017) "Corporate governance and intellectual capital disclosures in CEOs' statements", Nankai Business Review International, Vol. 8, No. 1, pp.2-21.

Zhang, J.Q., Zhu, H. and Ding, H.B. (2013) "Board composition and corporate social responsibility: An empirical investigation in the post Sarbanes-Oxley era", Journal of business ethics, Vol. 114, No. 3, pp.381-392. 
Scientific Journal for Financial and Commercial Studies and Researches (SJFCSR) Faculty of Commerce - Damietta University

\title{
حوكمتالشركات ومستوي الافصاح المتحقق منه كعوامل محددة لمستوي نغمتات الافصاح في البيئت المصريته
}

\author{
د. دمرو نزيه محمود عزت \\ أستاذ مساعد بقسم المحاسبة \\ كلية التجارة، جامعة المنصورة \\ anezat@iau.edu.sa
}

\begin{abstract}
ملخص البحث
يستهدف هذا البحث دراسـة مدي إعتبار كلا من حوكمـة الشركات ومستوب الافصـاح

المتحقق منه من ضمن العو امل المحددة الرئيسية لمستوي نغمـة (صياغة) الإفصاح في تقارير

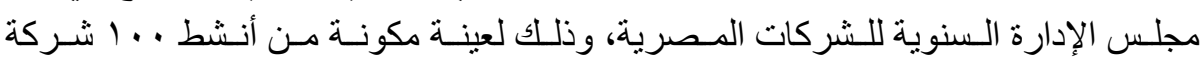

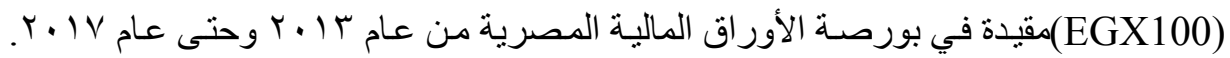

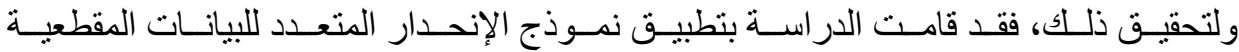

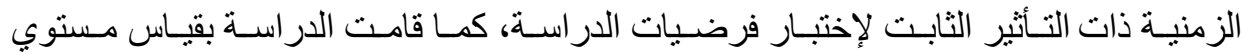

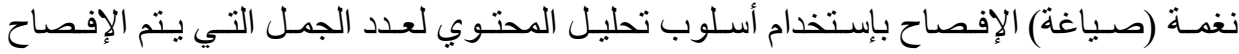

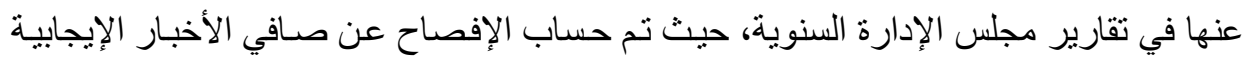

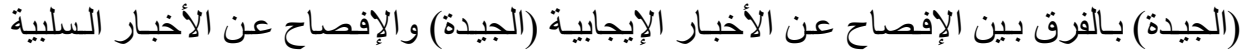

أوضحت النتائج أن تقارير مجلس الإدارة السنوية للشركات المصرية تفصح بشكل أكبر

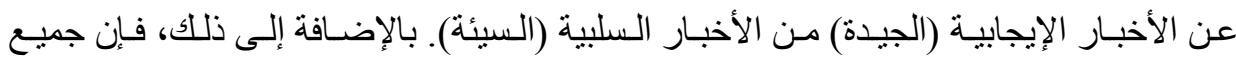

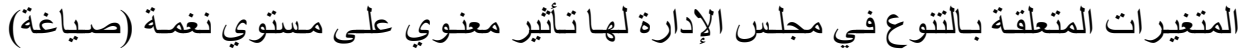
الإفصاح لتلك التقارير . فضلا عن ذلك، فإن متغير تثبيت (عدد سنوات بقاء) المدير النتفيذي التئي يعتبر المتغير الوحيد من المتغيرات المتعلقة بقوة تأثير المدير التنفيذي التي لديها تأثثير معنوي

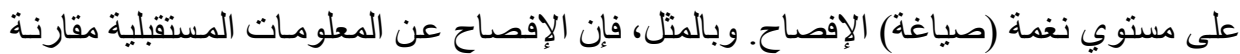

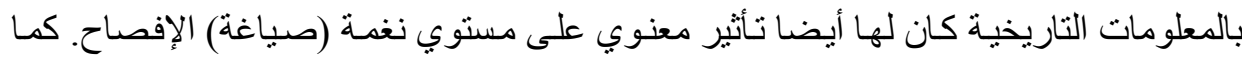

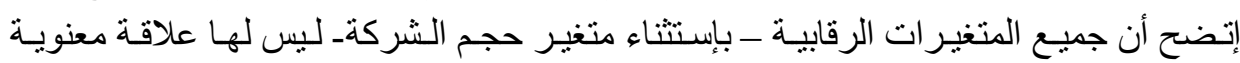
بمستوي نغمة (صياغة) الإفصاح.
\end{abstract}




\begin{tabular}{|c|}
\hline 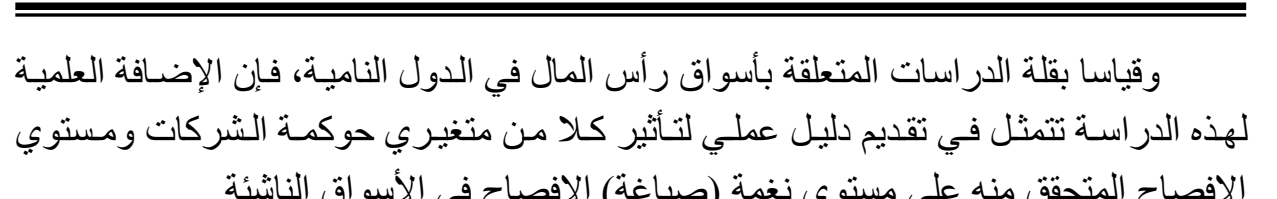 \\
\hline الإفصاح المتحقق منه على مستوي نغمة (صياغة) الإفصاح في الأسواق النانشئة \\
\hline
\end{tabular}

